\title{
Production of Noodles from Rice (Oryza sativa), African Yam Bean (Sphenostylis stenocarpa) and Rice Bran: A Tool for Ameliorating PEM and Hidden Hunger in Nigeria
}

\author{
Momoh Clement Owoicho, Abu Joseph Oneh, Yusufu Mohammed Ikagu \\ Department of Food Science \& Technology, University of Agriculture, Makurdi, Benue State, Nigeria \\ Email address: \\ momohclement86@gmail.com (M. C. Owoicho) \\ To cite this article: \\ Momoh Clement Owoicho, Abu Joseph Oneh, Yusufu Mohammed Ikagu. Production of Noodles from Rice (Oryza sativa), African Yam \\ Bean (Sphenostylis stenocarpa) and Rice Bran: A Tool for Ameliorating PEM and Hidden Hunger in Nigeria. International Journal of Food \\ Engineering and Technology. Vol. 4, No. 2, 2020, pp. 25-31. doi: 10.11648/j.ijfet.20200402.13
}

Received: July 12, 2019; Accepted: December 12, 2019; Published: September 3, 2020

\begin{abstract}
In this study, the chemical composition and sensory properties of noodles prepared from flour blends of broken rice $(\mathrm{R})$, African yam bean (AYB) and rice bran (B) were determined. A preliminary work was carried out to ascertain the optimal acceptable level of rice bran using 0 to $14 \%(\mathrm{w} / \mathrm{w})$ addition to rice flour noodle processing. Rice bran yielded the most acceptable noodles at $8 \%(\mathrm{w} / \mathrm{w})$. Consequently in the main study, the level of rice bran was maintained at $8 \%(\mathrm{w} / \mathrm{w}) \mathrm{while}$ AYB and rice flours were varied in the ratios of 100:0:0, 92:0:8, 83:9:8, 64:28:8 and 46:46:8\% giving a total of five samples. The noodles were characterized for proximate, mineral contents and sensory evaluation. The protein content of the noodles ranged between 5.8 and 18.4\%, increasing with increasing ratios of AYB. Potassium, sodium and magnesium were the predominant minerals in the noodles ranging from 57.00 to $200.40 \mathrm{mg} / 100 \mathrm{~g}, 1.60$ to $105.10 \mathrm{mg} / 100 \mathrm{~g}$ and 19.20 to $116.30 \mathrm{mg} / 100 \mathrm{~g}$ respectively. Cooking time ranged from 6.0 to $8.3 \mathrm{~min}$ with sample $46: 46: 8 \mathrm{R}$ : AYB: B taking the longest time to cook while the control (Rice noodle) cooked fastest. Sample 46:46:8R: AYB: B had the highest sensory scores of 7.3 on a 9 point hedonic scale for General acceptability.
\end{abstract}

Keywords: AYB, Rice, Rice Bran, Noodle

\section{Introduction}

Noodles are strings or strips of pasta produced through extrusion [1]. Claims have been made that noodles was of Chinese origin, however, due to the scarcity of physical evidence, it is unlikely that the question of origin can be answered with certainty [2]. Noodles are quick cooking foods that are increasingly gaining acceptance in Nigeria and gradually displacing most traditional diets that serve as breakfasts and snacks due to convenience, improved income, nutritional values, status symbol and job demands especially among urban dwellers [3]. The popularity of noodles has been attributed to its sensory appeal, versatility of form, low cost, ease of preparation at consumers end, nutritional content and long shelf life [4]. Pasta extrusion is known to result into products where the starch is slowly digested and absorbed [5]. The main ingredient in noodles is wheat and water mixed at appropriate concentrations [2]. Wheat is not only deficient in protein and other micronutrients as with cereals in general; it is also a foreign exchange depleter as a result of importation from scarce resources due to unfavorable climate for large scale production in Nigeria [6]. It was therefore thought worthwhile to produce noodle from broken rice and rice bran which are abundant in Nigeria.

Rice (Oriza sativa) is a cereal that is predominantly grown in all the ecological and dietary zones, and is used majorly as a staple food in Nigeria [7]. On average, milling $100 \mathrm{~kg}$ of paddy rice yields $55 \%$ of white rice, $15 \%$ broken grains, $10 \%$ of bran and $20 \%$ of hull [8]. Broken grains are less expensive and command low economic value [6]. Rice is low in protein and other micronutrient, because of its nutritional limitation, there is the need to supplement its protein content with locally available legumes and food sources that are high in protein [9]. Rice bran as rice by-product has higher protein value of $8-10 \%$ and it is a good source of minerals [10]. Rice bran is currently underutilized; it is used as agricultural waste 
and increases postharvest loss in spite of its high potential as a raw material for the preparation of functional foods and neutraceuticals [11]. Apart from the nutritional benefits of rice bran, it has anti nutritional factors. Stabilization and processing of rice bran helps to overcome these problems [12]. In view of the nutritional limitation of rice like other cereals, the use of African yam bean was considered to supplement the cereal protein in noodle preparation.

African yam beans (AYB) (Sphenostylis stenocarpa), an underutilized legume has the potential of providing nutritious food for the increasing population of the people in Nigeria [13, 14]. Nigeria is the highest producer of AYB [15]. AYB protein has been reported as a good source for adults and children in preparing complementary foods with about 19-23\% crude protein and high content of lysine $(7.5 \%)$, phenylalanine and tryptophan $[16,17]$.

In Nigeria where there is an increasing demand for readyto-eat, convenient and quick cooking food as well as malnutrition due to deficiency in protein calories and hidden hunger contributing to more than half a million deaths of newborn and growing children [18], AYB can be utilized as a supplementary protein in rice-based extruded foods to improve their nutritional quality. However, this will achieve the desired result as long as the sensory characteristics of the end product are not discernibly changed and the product is affordable to people at the bottom of the income pyramid. Incorporating rice with $\mathrm{AYB}$ and rice bran in noodle processing could result in low cost noodles with enhanced protein-energy, in addition rice bran will add reasonable amount of minerals which would serve as a potential solution to the consequences of hidden hunger in Nigeria. The nutritional quality of $\mathrm{AYB}$ and rice bran is however compromised by the presence of anti-nutritional factors, mostly: protease inhibitor, tannin and trypsin inhibitor [19], Extrusion and thermal processing denatures the naturally occurring anti-nutritional factors and thus has been widely used in reduction of anti-nutritional factors in plant based food products [20]. Although information on the use of rice in pasta production has been reported, there is little information on incorporating rice, rice bran and AYB flours for production of pasta despite the fact that these are indigenous food sources, there are produced in large quantities in Nigeria and are major sources of carbohydrate and protein respectively. This study thus, seeks to produce high protein-energy, low cost noodles from rice, AYB and rice bran composite flours and to evaluate the chemical composition, cooking, textural characteristics and sensory attributes of the noodles with the aim of promoting utilization of AYB and rice bran.

\section{Materials and Methods}

\subsection{Procurement of Materials}

Broken rice grains and rice bran were purchased from Miva Rice Mills, km3, Gboko road, Makurdi, Benue State. Creamed colored African yam bean seeds were purchased from Makurdi Modern Market, Benue State.

\subsection{Reagent}

Chemical used such as Sodium bicarbonate to facilitate removal of beany off-flavor and dehulling of African yam bean seeds is of analytical grade.

\subsection{Equipment}

A laboratory scale LSG65 twin screw extruder (Jianansaibaibainuo Technology LMT) with $15.5 \mathrm{~cm}$ screw length, $10.01 \mathrm{~cm}$ screw diameter and $0.8 \mathrm{~mm}$ die diameter was used for extrusion cooking. Extruder, tray drier (M/s Balaji enterprise, Shaharanpur, India) and moisture analyser (GRD $60 \mathrm{H}_{2} \mathrm{O}$ China) was used.

\subsection{Sample Preparation}

Broken rice grain and rice bran were washed with clean water, oven dried at $45^{\circ} \mathrm{C}$ for $15 \mathrm{~min}$ ), they were then ground into flour using laboratory grinder (M/S Sujata: New Delhi India) and sieved through a $0.5 \mathrm{~mm}$ size mesh and were packaged in Low density polyethylene bags prior to analyses. African yam bean flour was prepared as shown in Figure 1. The flour blend formulation is captured in Table 1 . The flour blends were conditioned to $35 \%$ moisture content, mixed manually and extruded at $120^{\circ} \mathrm{C}$ through $0.8 \mathrm{~mm}$ die diameter of a laboratory scale twin screw extruder (Jianansaibaibainuo Technology LMT) with $15.5 \mathrm{~cm}$ screw length, $10.01 \mathrm{~cm}$ screw diameter.

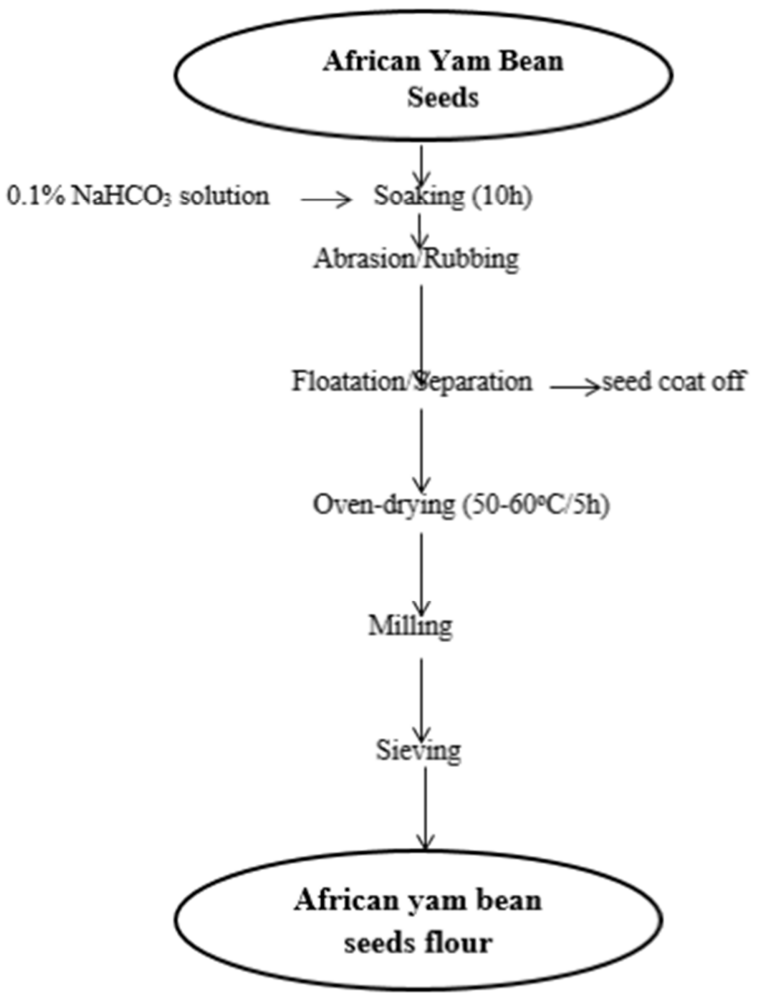

Source: Modified Nwosu et al. [23] $* \mathrm{NaHCO}_{3}$ Sodium Bicarbonate.

Figure 1. Flow Chart for Preparation of African Yam Beans Flour. 
Table 1. Flour Blends Formulation.

\begin{tabular}{llllll}
\hline & SAMPLES & & & \\
\cline { 2 - 6 } & A (Control) & B & C & D & E \\
\hline Broken rice flour & 100 & 92 & 83 & 64 & 46 \\
African yam beans flour & 0 & 0 & 9 & 28 & 46 \\
Rice bran flour & 0 & 8 & 8 & 8 & 8 \\
\hline
\end{tabular}

Extrusion of flour blends was done following the method described by Harper and Janson [1], for noodle production with some modification. Two (2) kilograms of each composite flours were conditioned to $35 \%$ moisture content; and kept for $30 \mathrm{mins}$. The composite flours were separately extruded at $120^{\circ} \mathrm{C}$ barrel temperature. The extruder was stabilized for each run with $2 \mathrm{~kg}$ whole rice flour at steady state operation; samples were collected in open pans. The extrudate was allowed to cool and dried for 3 hours in a tray drier at $60^{\circ} \mathrm{C}$ to a moisture content of $6-8 \%$, sealed in low density polyethylene bags and store in a refrigerator for subsequent analysis. Samples for analyses were milled into powders. [1].

\section{Analytical Methods}

The proximate analysis, amino acid analysis and mineral elements ( $\mathrm{Na}, \mathrm{Ca}, \mathrm{K}, \mathrm{Mg}$, and $\mathrm{Fe}$ ) to determine how much of major or macro components which include Moisture, Ash, Fiber, Fat and Protein were determined according to standard methods AOAC, [21]. The carbohydrates were determined by difference using the formula: $\%$ carbohydrate $=100-\%$ protein $+\%$ ash $+\%$ crude fiber $+\%$ crude fat $+\%$ moisture [22].

\subsection{Sensory Analysis}

Sensory evaluation of noodle was carried out using 20 panelists comprising of students and staff of Department of Food Science and Technology, University of Agriculture, Makurdi. Testing was conducted in the Sensory Laboratory of the Department of Food Science and Technology, University of Agriculture, Makurdi. Noodles were cooked and spiced with same quantity of commercially sold noodle spice. Panelists were required to evaluate the aroma, appearance, taste, mouth feel and overall acceptability of the cooked noodles using a 9-point hedonic scale with $1=$ dislike extremely, $2=$ dislike very much, $3=$ dislike moderately, 4=dislike slightly, $5=$ neither like nor dislike, $6=$ =like slightly, $7=$ like moderately, $8=$ like very much, and 9=like extremely [22].

\subsection{Statistical Analysis}

Statistical Package for Social Sciences (SPSS) V23 computer software was used to analyze the data. Means and Standard deviation were calculated where appropriate. One way Analysis of variance (ANOVA) was used to determine the treatment that was different from others in the various parameters tested; differences were considered significant at
95\% $(\mathrm{p}<0.05)$ significant level and 99\% $(\mathrm{p}<0.01)$ significant level where mentioned.

\section{Result and Discussion}

\subsection{Proximate Composition of Noodles Prepared from Rice, African Yam Bean and Rice Bran Composite Flours}

The results of proximate composition of noodles prepared from rice (R), African yam bean (AYB) and rice bran (B) composite flours presented in Table 2 showed that the protein contents ranged from 5.80 to $18.40 \%$. The highest and lowest values were observed in the samples 46:46:8R: AYB: B and 100:0:8R: AYB: B respectively. The carbohydrate $(94.10$ to $73.50 \%)$ content decreased, while protein, Ash (0.40 to $2.60 \%)$, fat $(0.23$ to $2.70 \%)$ and crude fiber ( 0.82 to $3.20 \%)$ content increased with increasing quantity of African yam beans flour in the noodle samples. The increase in the protein content could be attributed to high protein content for African yam beans, these values are in agreement with those reported by Nwosu $[24,25,14,26,27]$ are $23.2 \%, 21.0 \%, 22.3 \%$, $20.5 \%$ and $23.0 \%$ respectively. A similar trend was observed by Igbabul [28, 13] with cookies produced from wheat, cocoyam and African yam beans composite flours and extruded cakes from wheat and African yam beans flour blends respectively. All noodle samples have dissimilar protein content and are significantly different $(\mathrm{P}<0.05)$. Sample 46:46:8R: AYB: $\mathrm{B}$ had the highest protein content greater than that of wheat noodles $(12.30 \%)$. The result obtained for ash content showed significant difference $(p<0.05)$ among noodle samples. Similar values have been recorded by other researchers [27] with 'Kokoro' a Nigerian snack made from Maize and African yam bean flour blends: 1.87, 2.17 and 2.42\%. The relative high ash values of noodle samples may be attributed to the presence of rice bran used as part of the ingredients with $11.10 \% 9$ to $15 \%$ [11] ash content. Rice bran belongs to the class of compound known as flammable solids, because it easily catches fire upon ignition, thus producing more ash on combustion [29]. Also the high ash content of noodle samples may be attributed to the presence of more minerals in African yam beans [30], and rice bran, this further buttresses the nutritional importance of African yam beans. Hence incorporating African yam beans flour into noodle preparation could enhance the mineral intake of its consumers since ash is an indicative of the mineral contents in any food sample. The crude fat content of 
noodle samples ranged from 0.23 to $2.70 \%$, these values agrees with that reported by Priyanka [31] with extruded ready-to-eat snack produced using egg albumin cheese powder and African yam beans flour. Significant differences $(\mathrm{P}<0.05)$ were observed among samples. The increase in value obtained for fat content of noodle samples may be attributed to rice bran having high fat content, though kept constant (8\%), African yam beans flour was observed to contain low values of crude fat. Amatey [32] reported $2.10 \%$ for cream colored African yam beans flour. This makes product from African yam beans desirable since less fat content implies consumption of fewer calories which is beneficial from health standpoint as obesity, coronary heart disease and other illnesses attributed to consumption of too much fat could be minimized. Also low fat food products are less susceptible to rancidity and hence more shelf stable. Dietary fats that provide essential fatty acids (EFA) have been shown to enhance the taste and acceptability of foods, slow gastric emptying and intestinal motility, thereby prolonging satiety and facilitate the absorption of lipidsoluble vitamins [6]. The lipid component also helps to determine the texture, flavor and aroma of foods. The crude fiber content of noodle samples ranged from 0.82 to $3.20 \%$. Samples had dissimilar crude fiber and were significantly different $(p<0.05)$ from each other. Crude fiber is very important in adding bulkiness to food and for prevention of some disease of the colon. Fiber is important for the removal of waste from the body thereby preventing constipation and many health disorders. Consumption of vegetable fibre has been shown to reduce serum cholesterol level, risk of coronary heart disease, colon and breast cancer and hypertension; enhance glucose tolerance and increase insulin sensitivity [33]. CODEX [34] associated dietary fibre with properties such as decrease intestinal transit time and increases in stools bulk, fermentable by colonic micro-flora, reduce blood total cholesterol levels and reduce post-prandial blood glucose and /or insulin levels. The noodles therefore have a great potential for application as diabetic food because of the fiber source in their formulation that could be modified to generate a near perfect recipe for production of diabetic food/snacks. The carbohydrate content of noodle samples ranged from $94.10 \%$ to $73.50 \%$. This implies that the noodles are good sources of energy needed for normal body metabolism. However, carbohydrate content of noodle samples decreased with addition of African yam beans flour, Rice noodle had the highest value. This could be because rice flour used as the principal ingredient in the formulation has higher starch content than African yam beans flour. All noodle samples were significantly different $(\mathrm{P}<0.05)$ from each other in carbohydrate content. The values for carbohydrate are in agreement with values reported for flakes produced by substitution of wheat flour with rice flour and rice bran [35].

Table 2. Proximate Composition of Noodles Prepared from Rice, African yam bean and Rice bran Composite Flours (dry weight basis).

\begin{tabular}{llllllll}
\hline & & A & B & C & D & E & \\
\hline \multirow{3}{*}{ Nutrient } & Rice flour (\%) & 100 & 92 & 83 & 64 & 46 & \\
& AYB (\%) & 0 & 0 & 9 & 28 & 46 & LSD $_{0.05}$ \\
& Rice bran flour (\%) & 0 & 8 & 8 & 8 & 8 & \\
Protein & & $5.80^{\mathrm{c}} \pm 0.61$ & $6.40^{\mathrm{d}} \pm 0.19$ & $8.80^{\mathrm{c}} \pm 0.18$ & $13.10^{\mathrm{b}} \pm 0.27$ & $18.40^{\mathrm{a}} \pm 0.28$ & 0.73 \\
Ash & & $0.40^{\mathrm{c}} \pm 0.13$ & $1.40^{\mathrm{a}} \pm 0.10$ & $1.60^{\mathrm{c}} \pm 0.31$ & $2.10^{\mathrm{b}} \pm 0.24$ & $2.60^{\mathrm{a}} \pm 0.33$ & 0.32 \\
Crude fat & & $0.23^{\mathrm{b}} \pm 0.02$ & $1.60^{\mathrm{b}} \pm 0.10$ & $1.80^{\mathrm{b}} \pm 0.14$ & $2.20^{\mathrm{a}} \pm 0.22$ & $2.70^{\mathrm{a}} \pm 0.17$ & 0.59 \\
Crude fibre & & $0.82^{\mathrm{c}} \pm 0.07$ & $1.80^{\mathrm{c}} \pm 0.02$ & $1.90^{\mathrm{c}} \pm 0.0$ & $2.60^{\mathrm{b}} \pm 0.21$ & $3.20^{\mathrm{a}} \pm 0.19$ & 0.24 \\
Carbohydrate & & $94.10^{\mathrm{a}} \pm 1.7$ & $88.80^{\mathrm{b}} \pm 1.32$ & $85.90^{\mathrm{c}} \pm 1.29$ & $80.00^{\mathrm{d}} \pm 1.23$ & $73.50^{\mathrm{c}} \pm 0.99$ & 1.86 \\
\hline
\end{tabular}

Values are Mean \pm Standard deviation of triplicate determination. Mean values with common superscript letter (s) along each row are not significantly ( $\mathrm{p}>0.05$ ) different.

KEY: AYB=African yam beans flour.

\subsection{Mineral (mg/100g) Composition of Noodle Prepared from Rice, African Yam Bean and Rice Bran Composite Flours}

The mineral content (Table 3 ) of noodles produced from rice $(\mathrm{R})$, African yam bean (AYB) and rice bran (B) composite flours was found to vary significantly $(\mathrm{P}<0.05)$ with increasing African yam bean flour. This increase could be attributed to the high mineral content of African yam bean flour. 46:46:8R: AYB: B had the highest values for all minerals analysed. Potassium $(200.40 \mathrm{mg} / 100 \mathrm{~g})$ magnesium
$(116.30 \mathrm{mg} / 100 \mathrm{~g})$ and sodium $(105.00 \mathrm{mg} / 100 \mathrm{~g})$ were predominant minerals in the formulated noodles while Iron and calcium were found in low concentration, this is similar to the report of Edem [35] that low concentration was found of iron and zinc with extruded food from African yam bean flour and fonio flour. Higher mineral content were found in sample containing higher quantity of African yam bean flour which contributed to the relative high ash content in noodle samples. Uwaegbute [30] reported similar values for calcium content of African yam beans flour. 
Table 3. Mineral (mg/100g) Composition of Noodles Prepared from Rice, African Yam Bean and Rice Bran Composite Flour.

\begin{tabular}{|c|c|c|c|c|c|c|c|}
\hline & & Noodles & & & & & \\
\hline \multirow{3}{*}{ Nutrient } & Rice flour (\%) & 100 & 92 & 83 & 64 & 46 & \\
\hline & AYB $(\%)$ & 0 & 0 & 9 & 28 & 46 & $\mathrm{LSD}_{0.05}$ \\
\hline & Rice bran flour (\%) & 0 & 8 & 8 & 8 & 8 & \\
\hline $\mathrm{Na}$ & & $1.60^{\mathrm{d}} \pm 0.1$ & $2.00^{\mathrm{d}} \pm 0.0$ & $41.30^{c} \pm 1.1$ & $92.70^{\mathrm{b}} \pm 2.3$ & $105.10^{\mathrm{a}} \pm 1.7$ & 4.3 \\
\hline $\mathrm{Mg}$ & & $19.20^{\mathrm{d}} \pm 1.2$ & $96.60^{\mathrm{c}} \pm 1.2$ & $100.30^{\mathrm{c}} \pm 2.3$ & $111.00^{\mathrm{b}} \pm 1.3$ & $116.30^{\mathrm{a}} \pm 2.6$ & 3.8 \\
\hline $\mathrm{Ca}$ & & $17.00^{\mathrm{d}} \pm 1.0$ & $24.80^{c} \pm 1.1$ & $26.20^{\mathrm{c}} \pm 1.6$ & $34.20^{\mathrm{b}} \pm 1.4$ & $41.40^{\mathrm{a}} \pm 1.8$ & 2.8 \\
\hline K & & $57.00^{\mathrm{d}} \pm 2.1$ & $144.80^{\mathrm{c}} \pm 3.1$ & $152.90^{\mathrm{c}} \pm 2.4$ & $182.40^{\mathrm{b}} \pm 2.6$ & $200.40^{\mathrm{a}} \pm 3.6$ & 10.0 \\
\hline $\mathrm{Fe}$ & & $2.00^{\mathrm{b}} \pm 0.1$ & $3.60^{\mathrm{b}} \pm 0.1$ & $4.40^{\mathrm{b}} \pm 0.2$ & $6.40^{\mathrm{b}} \pm 0.6$ & $8.50^{\mathrm{a}} \pm 0.4$ & 2.1 \\
\hline
\end{tabular}

Values are Mean \pm Standard deviation of triplicate determination. Mean values with common superscript letter (s) along each row are not significantly (P>0.05) different.

KEY: AYB=African yam beans.

\subsection{Sensory Properties of Noodles Prepared from Rice, African Yam Bean and Rice Bran Composite Flours}

The sensory evaluation of noodles prepared from varying quantity of rice flour and African yam bean flour is presented in Table 4. Sensory perception varied significantly $(\mathrm{P}<0.05)$ among samples. Values obtained for taste showed a low level of acceptance of the noodles with increasing level of African yam beans. However, no significant difference $(\mathrm{P}>0.05)$ was obtained for appearance (color) of the samples with change in quantity (\%) of African yam bean flour. Higher sensory scores for flavour with increasing African yam bean flour in the sample shows the undesirable beany flavor usually associated with legume is negligible in the noodle. This may be attributed to the use of potassium Metabisulphite during African yam bean flour production, which might have off-set the beany flavor. There was no significant difference $(\mathrm{P}>0.05)$ for flavor of the samples with change in quantity (\%) of African yam bean flour. All noodle samples were generally accepted for all attributes evaluated as none scored below the minimum acceptable rating of 5 on a 9 point hedonic scale.
This indicates a high level of acceptance of the noodle prepared from rice, African yam beans and Rice bran composite flours, thereby improving the nutritional contents and as well as increasing the utilization of African Yam beans and also rice bran which was added as part of the ingredient.

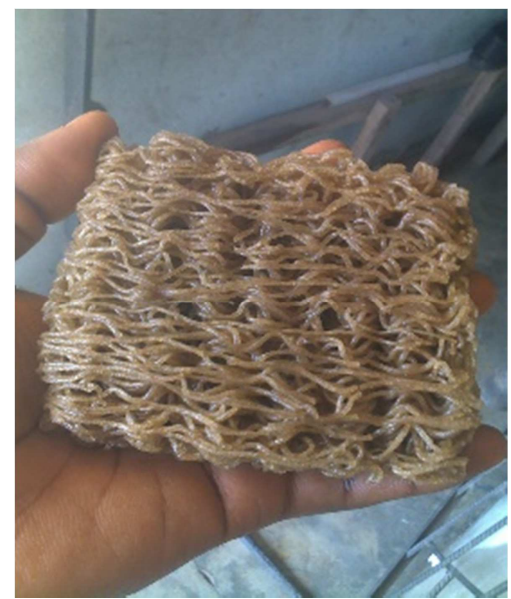

Figure 2. Noodles produced from rice broken rice, bran and $A Y B$.

Table 4. Mean Sensory Scores of Noodles Prepared from Rice, African yam bean and Rice bran Composite flours.

\begin{tabular}{|c|c|c|c|c|c|c|c|c|}
\hline & & Noodles & & & & & & \\
\hline \multirow{3}{*}{ Nutrient } & Rice flour (\%) & 100 & 92 & 83 & 64 & 46 & Wheat Noodle & \multirow{3}{*}{$\mathrm{LSD}_{0.05}$} \\
\hline & AYB (\%) & 0 & 0 & 9 & 28 & 46 & & \\
\hline & Rice bran flour (\%) & 0 & 8 & 8 & 8 & 8 & & \\
\hline Taste & & $6.90^{c} \pm 0.22$ & $6.90^{c} \pm 1.39$ & $6.30^{\mathrm{b}} \pm 1.08$ & $6.60^{\mathrm{b}} \pm 1.05$ & $6.80^{\mathrm{b}} \pm 1.35$ & $8.40^{\mathrm{a}} \pm 0.9$ & 0.34 \\
\hline Flavour & & $6.40^{\mathrm{a}} \pm 1.23$ & $6.30^{\mathrm{a}} \pm 0.97$ & $6.90^{\mathrm{a}} \pm 1.31$ & $6.90^{\mathrm{a}} \pm 0.94$ & $7.30^{\mathrm{a}} \pm 1.05$ & $7.90^{\mathrm{a}} \pm 1.1$ & 0.61 \\
\hline Color & & $5.90^{\mathrm{c}} \pm 1.82$ & $6.90^{\mathrm{b}} \pm 1.65$ & $6.70^{\mathrm{b}} \pm 1.18$ & $6.80^{\mathrm{b}} \pm 0.96$ & $6.70^{\mathrm{b}} \pm 1.09$ & $7.30^{\mathrm{a}} \pm 1.1$ & 0.29 \\
\hline Mouthfeel & & $6.80^{\mathrm{b}} \pm 1.82$ & $6.90^{\mathrm{b}} \pm 1.13$ & $6.60^{\mathrm{b}} \pm 0.84$ & $6.50^{\mathrm{b}} \pm 1.36$ & $6.70^{\mathrm{b}} \pm 1.09$ & $7.50^{\mathrm{a}} \pm 1.0$ & 0.31 \\
\hline General Acceptability & & $6.70^{\mathrm{b}} \pm 3.10$ & $6.70^{\mathrm{b}} \pm 1.10$ & $6.90^{\mathrm{b}} \pm 1.16$ & $7.30^{\mathrm{b}} \pm 1.1$ & $7.30^{\mathrm{b}} \pm 1.1$ & $8.20^{\mathrm{a}} \pm 1.3$ & 0.33 \\
\hline
\end{tabular}

Values are Mean \pm Standard deviation of triplicate determination. Mean values with common superscript letter (s) along each row are not significantly ( $>0.05$ ) different.

KEY: $\mathrm{AYB}=\mathrm{African}$ yam bean flour.

\section{Conclusion}

Extrusion of rice, African yam beans and rice bran composite flour produced acceptable noodles with significantly increased protein and ash contents in blend ratio 46:46:8R: AYB: B. Crude fat and crude fibre were similarly increased. The noodles could contribute significant amounts of protein and mineral with respect to $\mathrm{FAO} / \mathrm{WHO} / \mathrm{UNU}$ recommended daily intakes for $\mathrm{Mg}(130 \mathrm{mg} /$ day $)$, $\mathrm{Na}$ $(1000 \mathrm{mg} /$ day), Ca $(500 \mathrm{mg} /$ day $), \mathrm{K}(3000 \mathrm{mg} /$ day $)$ and $\mathrm{Fe}$ $(10 \mathrm{mg} /$ day). The sensory attributes showed that acceptable noodle can be produced from rice supplemented with rice bran and African yam beans. Blend formulation 46:46:8 R: 
AYB: B was mostly acceptable. This study therefore presents a way of increasing consumption and utilization of broken rice: with low economic value, rice bran (often disposed as agricultural waste) and African yam bean seeds (which are underutilized). African yam beans and rice bran could therefore serve as ingredients in food formulation to reduce malnutrition and hidden hunger among children and vulnerable groups in Nigeria, increase food security and further convert waste to wealth.

\section{References}

[1] Harper, J. and Janson, R. (2011). Production of nutritious precooked food in developing countries by low-cost extrusion technology. Food Rev Int 1:27-97.

[2] Chen, Z., Sagis, L., Legger, A., Linssen, J. P. H., Schols, H. A. and Voragen, A. G. J. (2003). Evaluation of starch noodles made from three typical chinese sweet potato starches. Journal of Food Science. 67: 3342-3347.

[3] Okafor, G. I. and Usman, G. O. (2015). Production and evaluation of breakfast cereal from blends of African Yam beans (sphenostylis stenocarpa), Maize (Zea mays), and deffated coconut (cocus Nucifera). Journal of food processing and preservation (in pres). DOI: 10.1111/jfpp.12060 (Early view).

http://onlinelibrary.wiley.com/doi/10.111/jfpp.12060/1bstract.

[4] Anounye, J. C., Jigam, A. A. and Ndaako, G. M. (2012). Effects of extrusion cooking on the nutrients and anitnutrients composition of pigeon pea and unripe plantain blends. Journal of Applied Pharmaceutical Science, 2 (5): 58-162.

[5] Wolever, T., Whentit, P., Dedoba, W. T. (2013). Function of Resistant starch in extruded foods produced from plantain and banana specie. Journal of food and applied Bioscience. 2 (1): $1-5$.

[6] FAO (2011). Fats and fatty acids in human nutrition: Report on an expert consulation. FAO food and nutrition paper 91, pp 55. Rome: food and Agricultural Organization of the United State.

[7] Erhabor, P. and Ojogho, O. (2011). Demand analysis for rice in Nigeria. Journal of food and Agric. Technology. 9 (2): 66-74.

[8] Shih, F. F. (2003). An update on processing of high protein rice products, USA Rice Council. pp 34.

[9] Nnam, N. M. (2003). Nutrient composition and sensory evaluation of snacks produced from flour blends of some Nigerian indigenous food crops. Nigerian Journal of Nutritional Sciences. 24 (2), 52-56.

[10] Faiyaz, A., Kalpana, P., Suryanarayanaiyer, V., Shashikala, P. and Krishnapura, S. (2007). Improved shelf-life of rice bran by domestic heat processing and assessment of its dietary consumption in experimental rats. Journal of Science, Food and Agric., 87: 60-67.

[11] Pitchaporn, W., Channarong, C. and Sirithon, S. (2009). Substitution of wheat flour with rice flour and rice bran in flake products: Effects on physical, chemical and antioxidant properties. World applied science journal 7 (1): 50.

[12] Mohammed, A. S., Ara, H., Jabin S. A. Abedin, A. Azad, A.
K., Hossain, A. and Ara, U. (2014). Nutritional composition and stabilization of local variety rice bran BRRI-28. Int. Journal. of sci \& tech. 3 (5): 306.

[13] Ekop, A. S. (2006). Changes in Amino Acid composition of African yam beans (Sphenostylisstenocarpas) and African locust beans (Parkiafilicoida) on cooking. Pakistan Journal of Nutrition 5 (3): 254-256.

[14] Eneche, H. E. (2005). Enrichment of starchy flours with African yam bean protein concentrate. Nigerian Journal of Nutrition Science. 26. 30-37.

[15] Potter, D. (1992). Economic botany of Sphenostylis (Leguminosae). Economic Botany, 46, 262-275. http://dx.doi.org/10.1007/BF02866625.

[16] Gloria, C. O. (2012). Amino acid profile of raw and extruded blends of African yam bean (Sphenostyliss tenocarpa) and cassava flour. American journal of food and nutrition 2 (3): 65-68, retrieved online: http://www.scihub.org/AJFN.

[17] Uguru M. I. and Madukaife S. O. (2001). Studies on the variability in agronomic and nutritive characteristics of African yam bean (Sphenostylis stenocarpa Hochst ex. A. Rich. Harms). Plant Prod. Res. J. 6: 10-19.

[18] Onyezilli, P. (1999). Protein calorie deficiency: Control efforts. New times Purblisher, Abia. 22.

[19] Akinmutimi, A. H., Amaechi, N. and Unogu, M. (2006). Evaluation of raw african yam beans meal as a substitute for soyabeans meal in the diet of weaners rabbit. Journal of Animal and Veterinary, 5 (11): 907-911.

[20] Olapade, A. A. and Aworh, O. C. (2012). Chemical and nutritional evaluation of extruded complementary foods from blends of fonio (Digitaria Exilis Stapf) and cowpea (Vigna Unguiculata L. Walp) flours. International Journal of Food and Nutrition Science 3 (1): 4-5.

[21] AOAC (2012). Official Methods of Analysis. 20th edition. Association of Official Analytic Chemists. Washinton D. C.

[22] Ihekoronye, A. I. and Ngoddy, P. O. (1985). Integrated Food Science and Technology for the Tropics, MacmillanPub. Ltd, London. pp. 243-248.

[23] Nwosu, J. N., Onuegbu, N. C., Ogueke, N. O., Kabuo, N. O. and Omeire, G. C.(2014). Aceptability of moin-moin produced from blends of african yam bean (Sphenstylisstenocarpa) and cowpea (Vignaunguiculata). Inter. Journal of curr. microbiology and applied sci. 3 (5): 996-100.

[24] Ameh, G. I. (2007). Proximate and mineral composition of seed and tuber of African yam beans, Sphenostylisstenocarpa (Hoechst. Ex. a. rich) Harms. Bio-Research, 3, 14-20.

[25] Obatolu, V. A. and Cole, I. H. (2000). Functional property of complementary blends of soybean and cowpea with malted or unmalted maize. Food Chemistry 70. 147-153.

[26] Oshodi, A. A. (1997). In vitro Multienzyme digestibility of protein of six varieties of African yam beans flour. Journal of Science, Food and Agriculture, 69, 373-377. http://dx.doi.org/10.1002/jsfa.2740690315.

[27] Idowu, A. O. (2015). Nutrient composition and sensory properties of kokoro (a Nigerian snack) made from maize and African Yam bean flour blends. Inter. food research journal, 22 (2): 739-74. 
[28] Igbabul, D. I., Benbella, M. I and Umana, E. T. (2014). Physical and sensory properties of cookies produced from composite flours of wheat, cocoyam and African yam beans. Journal of food science. 4 (2) 150-157.

[29] Wasserman, R. (2010). Properties of coconut fibre. http://www.livestrong.com/article/249254--propertiesofcoconutfiber/.Accessed 19/8/10.

[30] Uwaegbute, A. C., Ukegbu, P. O. and Ikpeoha, A. (2012). Effect of germination on cooking, nutrient composition and organoleptic qualities of African Yam beans (sphenostylis stenocarpa). Journal of Biology, Agriculture, and Health care 2: $28-32$.

[31] Priyanka, W., McWatters, K. H, Beuchat, L. R., and Phillips, R. D. (1997). Functional characteristics of cowpea (Vigna unguiculata) flour and starch as affected by soaking, boiling and fungal fermentation before milling. Food chemistry, 58, 361-372.
[32] Amoatey, H. M., Klu, G. Y. P., Bansa, D., Kumaga, F. K, Aboagye, L. M., Benne-Lartey, S. O. and Gamedoagbao, D. K. (2010). African Yam Beans (sphenostylis stenocarpa): A neglected crop in Ghana, West African Journal of Applied Ecology. 1: 53-60.

[33] Hassan, T., and Usman, T. (2004). Function of dietry fiber in the body. Cambridge wood head publishing. Pp. 110-122.

[34] CODEX (2009). Report on the 30th session of the CODEX committee on Nutrition and foods for special dietary uses, Cape town, SA, 3-7 November, 2008.

[35] Wanyo, P., Schoenlechner, R., Meeso, N and Siriamornpun, S. (2014). Antioxidant activities and sensory properties of rice bran with marigold. Journal of food and applied Bioscience 2 (1): 1-14.

[36] Edem, D. O., Amugo, C. I. and Eka, O. U. (1990). Chemical composition of the yam bean (Sphenostylis stenocarpa). Tropical science 30: 59-63. 